\title{
鼻副鼻腔未分化癌の検討
}

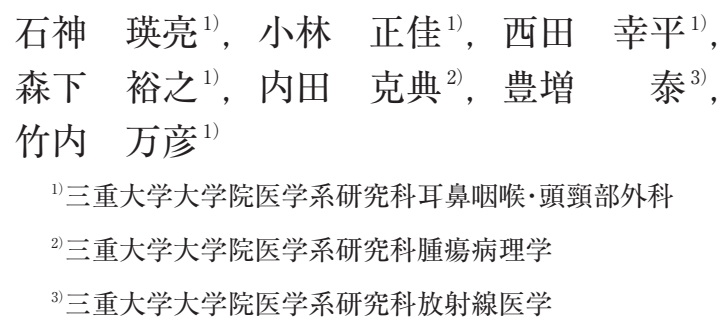

鼻副鼻腔未分化癌は希少がんであるため, 治療法がまだ標準化されていない。今回我々が経験した鼻副鼻胿 未分化癌 4 例の診療経過を報告する。全症例とも進行期（Stage IVAまたはIVB）であった。症例 1:39歳女性。 複視で発症した海綿静脈洞と視交叉への浸潤を伴う蝶形骨洞癌で, 化学放射線療法と広範囲定位放射線治療を 施行した結果, 腫瘍が消失して視力が回復し, 現在 11 年間無病生存中である。症例 $2: 65$ 歳女性。鼻腔癌で内 視鏡下経鼻的前頭蓋底腫瘍切除・再建術と術後化学放射線療法を施行し， 2 年経過して無病生存中である。症 例 3：47歳女性。頭蓋内と眼窩内一の浸潤を伴う篩骨洞癌で, 開頭と経鼻内視鏡下の複合的アプローチ手術と 術後化学放射線療法を施行した。局所は制御できたが, 治療後6力月で遠隔転移再発により死亡した。症例 4 : 52 歳女性。眼窩と上顎への浸潤と頸部リンパ節転移を伴う節骨洞癌で, 化学放射線療法を施行して原発巣とリ ンパ節転移は制御できたが, 治療後 5 カ月経過して遠隔転移再発を生じて 7 月後に死亡した。以上, 4 例中 2 例 が無病生存であるが, 全例, 局所は制御されていた。根治切除, 化学放射線療法もしくはこれらの併用は鼻副 鼻腔未分化癌の局所制御には効果的であるが，治療後に遠隔転移を生じると予後不良になると考えられる。

キーワード：鼻副鼻胿未分化癌，手術，化学療法，放射線治療

\section{Sinonasal Undifferentiated Carcinoma}

\section{Eisuke Ishigami $^{1)}$, Masayoshi Kobayashi ${ }^{1)}$, Kohei Nishida ${ }^{1)}$, Hiroyuki Morishita ${ }^{1)}$, Katsunori Uchida', Yutaka Toyomasu ${ }^{3)}$, Kazuhiko Takeuchi ${ }^{1)}$}

\footnotetext{
${ }^{1)}$ Departments of Otorhinolaryngology-Head and Neck Surgery, Mie University Graduate School of Medicine

${ }^{2}$ Departments of Oncologic Pathology, Mie University Graduate School of Medicine

${ }^{3}$ Departments of Radiology, Mie University Graduate School of Medicine
}

Sinonasal undifferentiated carcinoma (SNUC) is a rare cancer, for which optimal treatment is undefined due to the limited numbers of studies. Here we report four cases of SNUC. Case 1: A 39-year-old woman had inoperable sphenoidal sinus SNUC with invasion of the cavernous sinus and optic chiasma that caused bilateral total blindness. She underwent chemoradiotherapy (CCRT) followed by stereotactic radiosurgery that was curative, and she has survived for 11 years with restored visual function. Case 2: A 65-year-old woman with nasal cavity SNUC underwent endoscopic endonasal anterior skull base surgery followed by CCRT. The treatment 
was curative and she has survived for two years. Case 3: A 47-year-old woman with ethmoid sinus SNUC with dural and orbital invasion underwent radical resection followed by CCRT. Six months later, distant metastasis occurred and this led to her death. Case 4: A 52 -year-old woman with inoperable ethmoid sinus SNUC with orbital invasion underwent CCRT, and showed a complete response. However, 5 months later the patient died due to distant metastasis. All four cases were in an advanced stage (IVA or IVB). Good local control of the primary tumor was achieved, but only two patients without distant metastasis survived. Thus, we conclude that radical resection and/or CCRT are effective for control of local SNUC, but that distant metastasis leads to an extremely poor prognosis.

Key words : Sinonsal undifferentiated carcinoma (SNUC), Surgery, Chemotherapy, Radiotherapy

(2020年 7 月 10 日受稿, 2021 年 4 月 7 日受理)

\section{はじめに}

鼻副鼻腔未分化癌は急速な経過をたどる悪性腫瘍で ある。年齢調整罹患率が 10 万人あたり 0.02 人 $^{1)}$, 鼻副鼻 腔癌の $2 \%$ 未満 2 であり, 希少がんとされている。治療成 績はNational Cancer Data Baseで 5 年生存率 $42.2 \%$ と報 告 ${ }^{3)}$ されているが，データベースを用いた報告以外には 大規模な検討は未だなされておらず，データの蓄積が少 ない。それゆえに標準治療法もまだ確立されていない。 今回当施設で経験した鼻副鼻腔未分化癌4症例を紹介し, その臨床像と考察を報告する。なお, 本検討は三重大学 の倫理審査にて事前に承認を受けた（承認番号H20180602018 年 10 月 23 日承認)。

\section{症例呈示}

症例 $1: 39$ 歳 女性

主訴 : 複視

現病歴：当科受診 1 月前より複視，左眼瞼下垂が出 現し, 近医脳神経外科を経て当院脳神経外科を紹介受診 し，同科入院となった。MRIで左蝶形骨洞から海綿静脈 洞内へ伸展する腫瘍を認め（図 1 ）, 視交叉浸潤により入 院後全盲に至った。副鼻腔腫瘍の精査加療目的に当科へ 紹介された。
病理組織学的所見：円形細胞腫瘍で, 不整型腫大核と 顕性化核小体を持ち, 胞体のそしい異型細胞が充実性に 増生していた。ヘマトキシリン・エオジン（HE）染色 所見および免疫染色所見（表1）から鼻副鼻腔未分化癌 と診断された。この診断時には小細胞癌も鑑別診断に挙 げられたが, 形態学的に核小体が顕在化し，核が水泡状 である所見が小細胞癌とは異なるため，最終的に未分化 癌の診断となった。

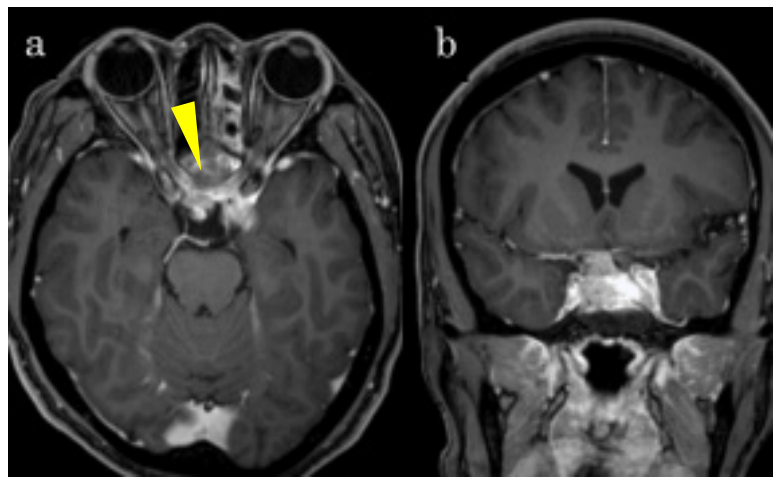

図1 症例 1 のRI像。造影 $\mathrm{T} 1$ 強調画像では高信号で造影効 果のある腫瘍を認める。 $\mathrm{a}$ :水平断像。左蝶形骨洞から 左篩骨洞にかけて前方へ伸展しており，後方へは海綿 静脈洞, 視交叉への伸展も認める (矢頭)。b : 冠状断 像。海綿静脈洞に腫瘍の伸展を認める。

\section{表 1 各症例の代表的免疫染色結果}

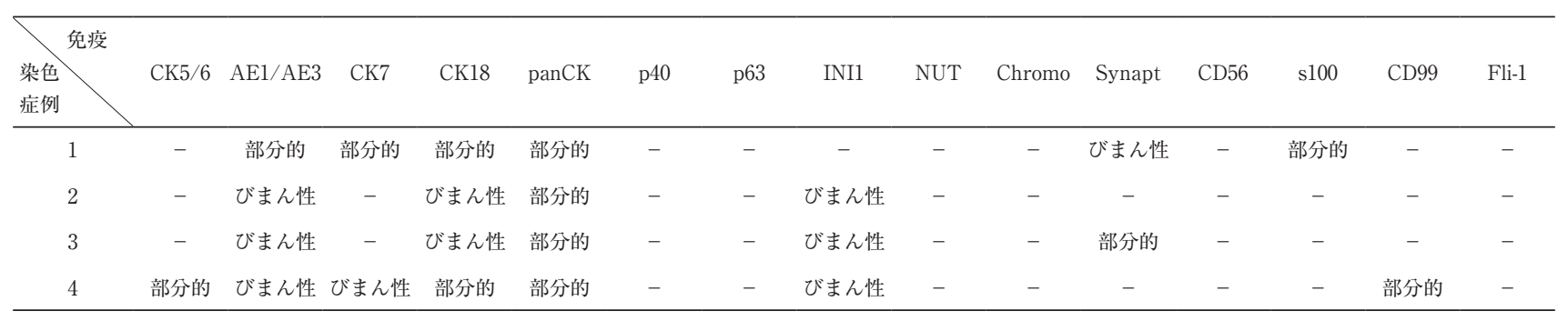


診断：左蝶形骨洞未分化癌 頭蓋内浸潤

治療：根治目的で化学放射線療法を施行した。化学療 法はFP療法（フルオロウラシル $800 \mathrm{mg} / \mathrm{m}^{2}$ : day 1-5, シ スプラチン $80 \mathrm{mg} / \mathrm{m}^{2}:$ day 6) を4コース，4週間毎に施 行した。放射線治療は通常照射 $36 \mathrm{~Gy} / 12$ 回とした。海綿 静脈洞浸潤もあったため, 治療開始より約半年後に広範 囲定位放射線治療（ガンマナイフ ${ }^{\circledR}$ ) $10 \mathrm{~Gy} / 1$ 回を追加し た。両側視神経はいずれも $41.0 \mathrm{~Gy}$ （通常照射 $36 \mathrm{~Gy} / 12$ 回＋ガンマナイフ $5 \mathrm{~Gy} / 1$ 回)が照射された。治療後, MRI で腫瘍は消失して扮り（図 2 ), 視力は右 0.9 , 左 0.1 まで 回復した。複視, 左眼瞼下垂も改善した。現在 11 年無病 生存中であり，視機能は保たれている。

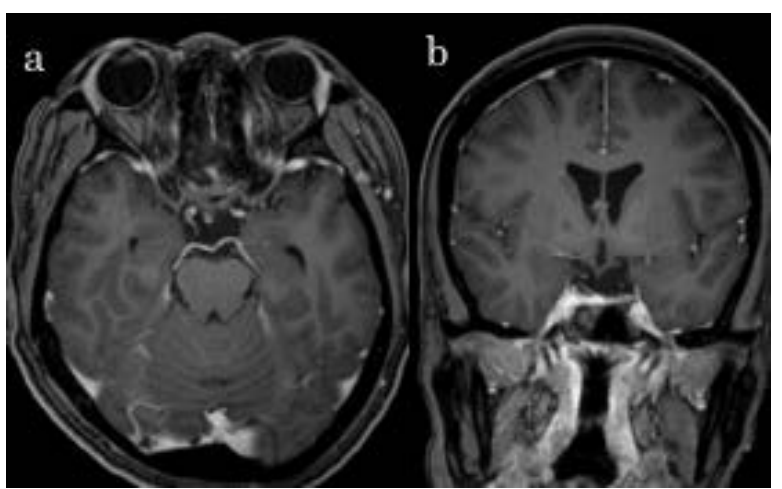

図2 症例 1 の治療後MRI像。造影 $\mathrm{T} 1$ 強調画像で腫瘍の消失 を認める。 $\mathrm{a}$ : 水平断像。 $\mathrm{b}$ : 冠状断像。
症例 $2: 66$ 歳 女性

主訴：鼻出血

現病歴：当院受診 3 力月前に鼻出血にて近医耳鼻咽喉 科診療所を受診した際に右鼻内に腫瘍を指摘され, 生検 で嗅神経芽細胞腫と診断され，当科へ紹介された。

検査所見：鼻内内視鏡所見では右嗅裂に平滑なポリー プ様の腫瘍を認め（図3-a)，CT，PET-CTでは腫瘍は嗅 裂に限局していた（図3-b,c，d）。MRI造影T1強調画像 で右嗅裂に造影効果のある等信号の腫瘍像を認め, 右穊 骨洞に低信号の院影を認めた。頭蓋内や視交叉への浸潤 所見はなかった（図3-e, f)。前医でHE染色された生検 組織標本を再検討したところ，円形細胞腫瘍であった。 確定診断には至らなかったが，嗅神経芽細胞腫として矛 盾はしない所見であった。

治療：右鼻膑腫瘍・嗅神経芽細胞腫の術前診断で内視 鏡下経鼻的広範囲頭蓋底腫瘍切除・再建術を施行した。 最初に腫瘍周囲の正常粘膜に見えた部位から術中迅速病 理検査によるマージンスタディを 9 カ所で施行したとこ ろ，8力所が腫瘍陽性の結果であり，さらに外縁部から マージンスタディを繰り返し，陰性となった部位を切除 線とし, 腫瘍を一塊摘出した（図4)。前頭蓋底の切除範 囲は前方を篩孔前方の前頭洞後壁，後方を蝶形骨洞前壁 上端，内側を正中，外側を篩孔外側までとし，鵎冠を含 めて骨削除し, 右嗅球, 右嗅索を含めて硬膜を切除した。 頭蓋底切除ラインの断端で硬膜浸潤がないことをマージ

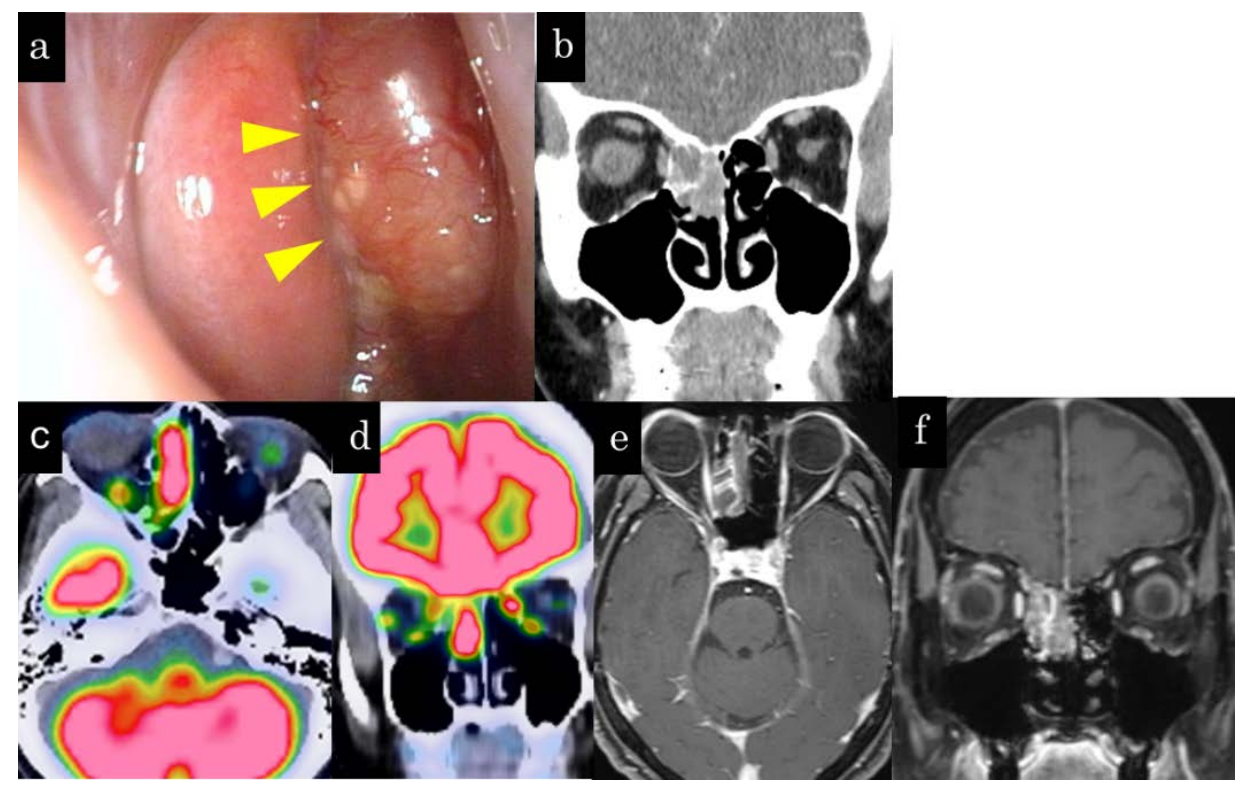

図3 症例 2 の治療前所見。 $\mathrm{a}:$ 症例 2 の鼻内内視鏡所見。嗅裂に表面平滑な腫瘍を認める (矢頭)。 $\mathrm{b} ：$ 症例 2 のCT像。嗅裂，篩 骨洞に軟部陰影を認める。c, d : 症例 2 のPET-CT像。FDG集積は嗅裂に限局している。c：水平断像。d：冠状断像。e, $\mathrm{f}$ : 症例 2 のMRI像。造影 $\mathrm{T} 1$ 強調画像では等信号で造影効果のある腫瘍を認める。 $\mathrm{e}$ : 水平断像。右嗅裂から右総鼻道，右穊 骨洞にかけて腫瘍を認める。視交叉への伸展は認めない。f：冠状断像。右嗅裂から右総鼻道，右篩骨洞にかけて腫瘍を認 める。頭蓋内への伸展は認めない。 


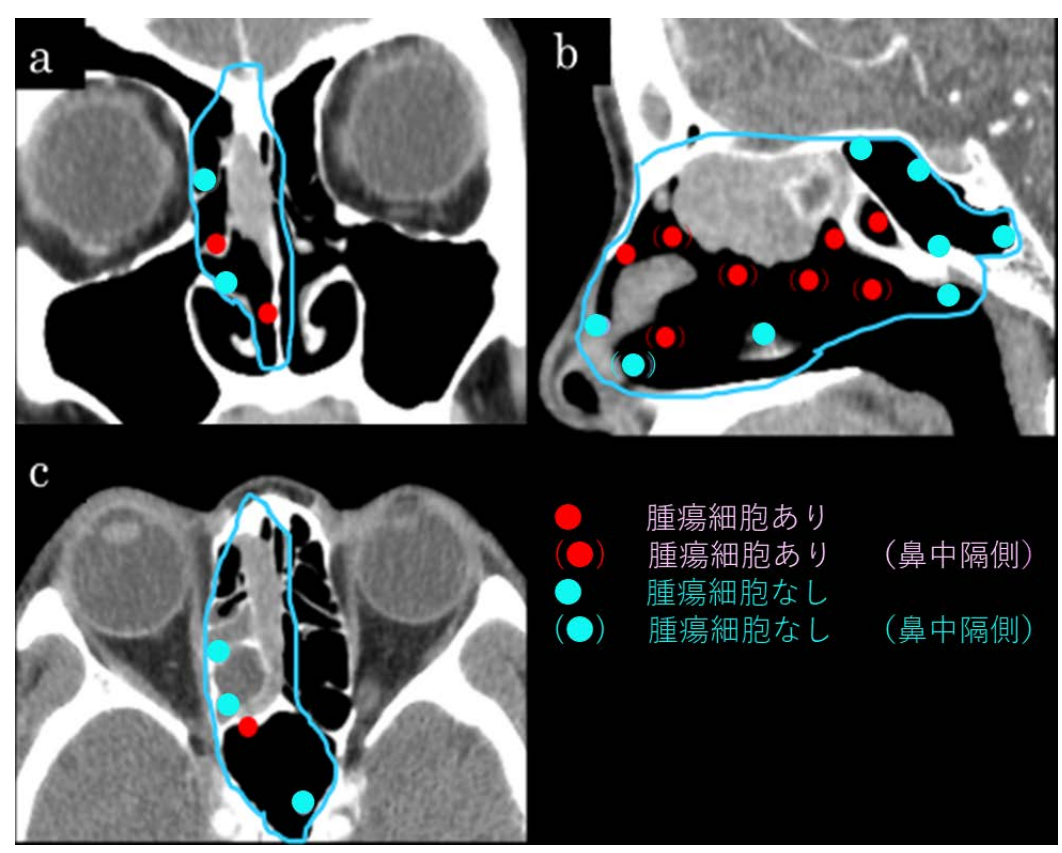

図4 症例 2 のT像。術中マージンスタディでの腫瘍浸潤の有無を示した。腫瘍浸潤あり (赤丸), 腫瘍浸潤なし (青丸)。切除 線を示した (実線)。 $\mathrm{a}$ : 冠状断像。 $\mathrm{b}$ : 矢状断像。 $\mathrm{c}$ : 水平断像。

ンスタディで確認した。眼窩内側壁に腫瘍の浸潤所見が 認められなかったが，安全に前篩骨動脈を結紮処理する ためにこの周囲の眼窩紙様板を一部切除した。頭蓋底再 建は大腿筋膜, 鼻中隔軟骨, 大腿笳膜, 総鼻道底と下鼻 道の粘膜も含めた左拡大有茥鼻中隔粘膜弁で 4 層再建と した。手術時間は 11 時間 58 分, 出血量は $50 \mathrm{ml} ゙$ あった。 上記手順により切除断端陰性で根治切除となった。術後 永久病理診断で未分化癌が判明した。画像上蝶形骨洞に 陰影は認めないが, 術中マージンスタディで蝶形骨洞粘 膜にも腫瘍細胞を認め, 切除したため, 術後診断は右鼻 腔未分化癌cT4aN0M0, Stage IVAであった。

手術検体の病理組織学的所見：円形細胞腫瘍で，明瞭 な 1 個の核小体を含む水胞状円形核と境界不明瞭な淡 好酸性胞体を有する腫瘍細胞が充実性に増生していた (図5)。HE所見および免疫染色所見（表1）から鼻副鼻 腔未分化癌と診断された。なお, 蝶形骨洞とその周囲へ 伸展していた部分では, 病理学的検査で腫瘍細胞は上皮 の粘膜下組織までの深達度で浅く広がり, さらに深部の 骨膜，軟骨膜への浸潤所見は認められなかった。

術後経過：以上により根治切除を成し得たが，悪性度 の高い未分化癌であることから術後 2 週間の時点で術後 化学放射線療法を施行した。化学療法はFP療法を 3 コー ス，4週間毎に施行した。放射線治療はIMRT（intensity modulated radiation therapy：強度変調放射線治療）で $60 \mathrm{~Gy} / 30$ 回とした。右視神経への線量は52.7 Gy, 左視神 経への線量は 50.9 Gy となっている。治療後MRIで腫瘍

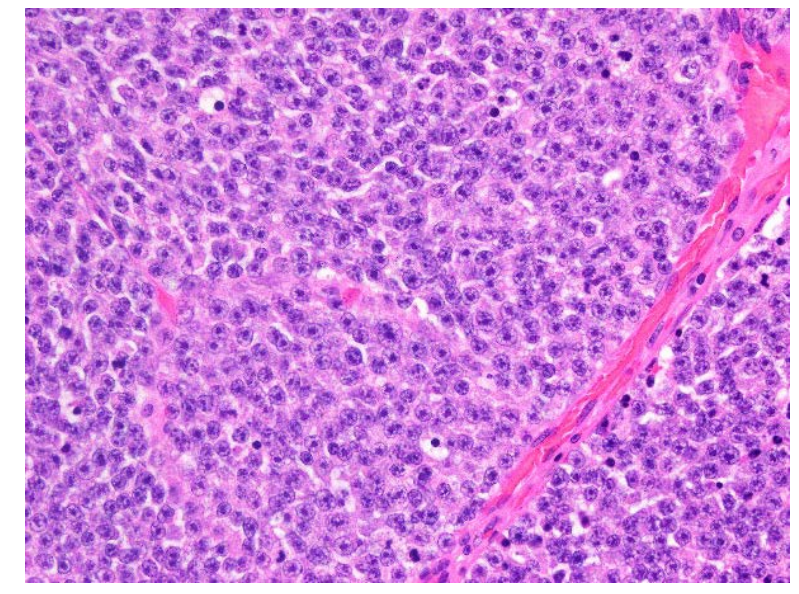

図 5 症例 2 の病理組織像。明瞭な 1 個の核小体を含む水胞状 円形核と境界不明瞭な淡好酸性胞体を有する腫瘍細胞 が充実性に増生している。

の再発所見はなく, 現在 2 年間無病生存中である（図6）。

症例 $3: 47$ 歳 女性

主訴：左鼻閉，嗅覚低下

現病歴：当院受診 1 年前より嗅覚低下あり, 近医耳鼻 咽喉科診療所のステロイド点鼻薬で一時的に軽快した が, 左鼻閉が徐々に増悪し, 腫瘍を疑われ当科へ紹介さ れた。

CT所見：左上顎洞, 左篩骨洞, 左蝶形骨洞, 左総鼻 道にわたり軟部陰影を認め, 頭蓋底の骨破壊を伴い頭蓋 内への伸展を認めた（図7-a, b)。 


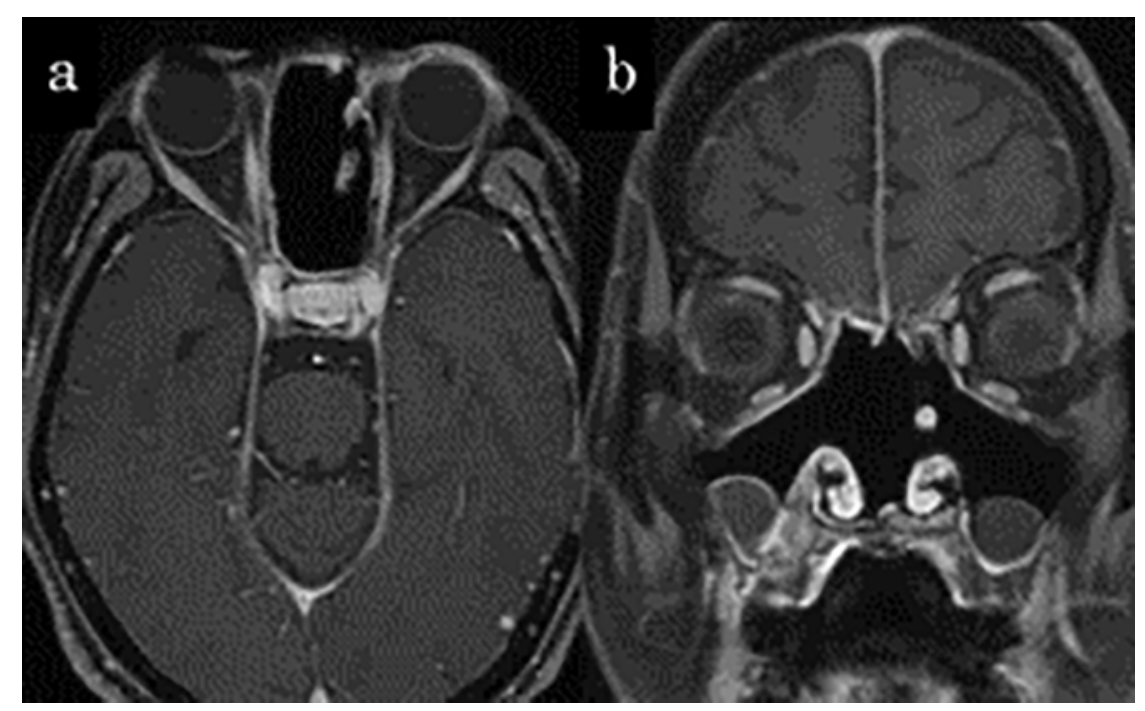

図6 症例 2 の治療後MRI像。造影T1強調画像で腫瘍の消失を認める。a：水平断。 $\mathrm{b}$ : 冠状断。

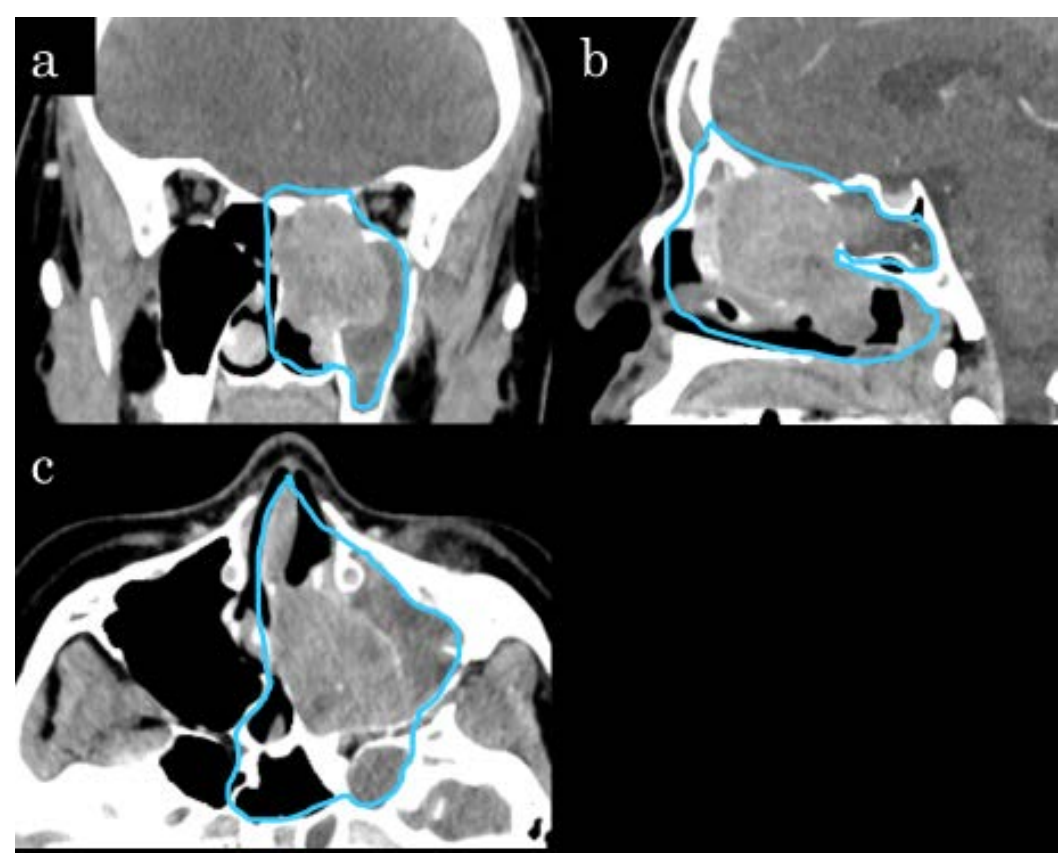

図7 症例 3 のCT像。左上顎洞, 左篩骨洞, 左蝶形骨洞, 左総鼻道にわたり軟部陰影を認め, 頭蓋底の骨破壊を伴い頭蓋内への 伸展を認める。切除線を示した (実線)。 $\mathrm{a}$ ：冠状断像。 $\mathrm{b}$ ：矢状断像。 $\mathrm{c}$ ：水平断像。

MRI所見：造影T1強調画像で，等信号で造影効果の ある腫瘍を左篩骨洞から左上顎洞, 左上鼻道, 左中鼻道, 左総鼻道, 左蝶形骨洞にわたり認め, 硬膜浸潤を疑う硬 膜肥厚所見も認めた。左前頭蓋底には近接しているが, 同部の浮腫，浸潤所見は認めなかった（図8-a,b)。

病理組織学的所見：円形細胞腫瘍で, 細胞質に乏しく 濃染する円形腫大核を有する腫瘍細胞が充実性に増生し ていた（図9）。HE所見および免疫染色所見（表1）から 鼻副鼻腔未分化癌と診断された。

診断: 左篩骨洞未分化癌。cT4bN0M0, Stage IVB
治療：開頭と鼻内内視鏡下の複合的アプローチで広範 囲頭蓋底腫瘍切除・再建術を施行した。術中マージンス タディを施行し, 切除断端陰性, 根治切除と評価できた （図7）。頭蓋底切除範囲は, 外側は正中から左へ $3 \mathrm{~cm}$, 内側は正中から右へ $1.5 \mathrm{~cm}$, 前部は前頭洞後壁, 後部は 鞍結節前方とする範囲であり，この範囲の骨削除と硬膜 切除を施行した。蝶形骨洞へも腫瘍の伸展を認めたが, 蝶形骨洞粘膜は陰性であり，蝶形骨洞〜上咽頭上壁粘膜 を腫瘍と一塊に切除した。頭蓋底欠損部は頭蓋骨膜弁を 残存硬膜と縫合し, その上から大腿筋膜で被覆し, 鼻中 


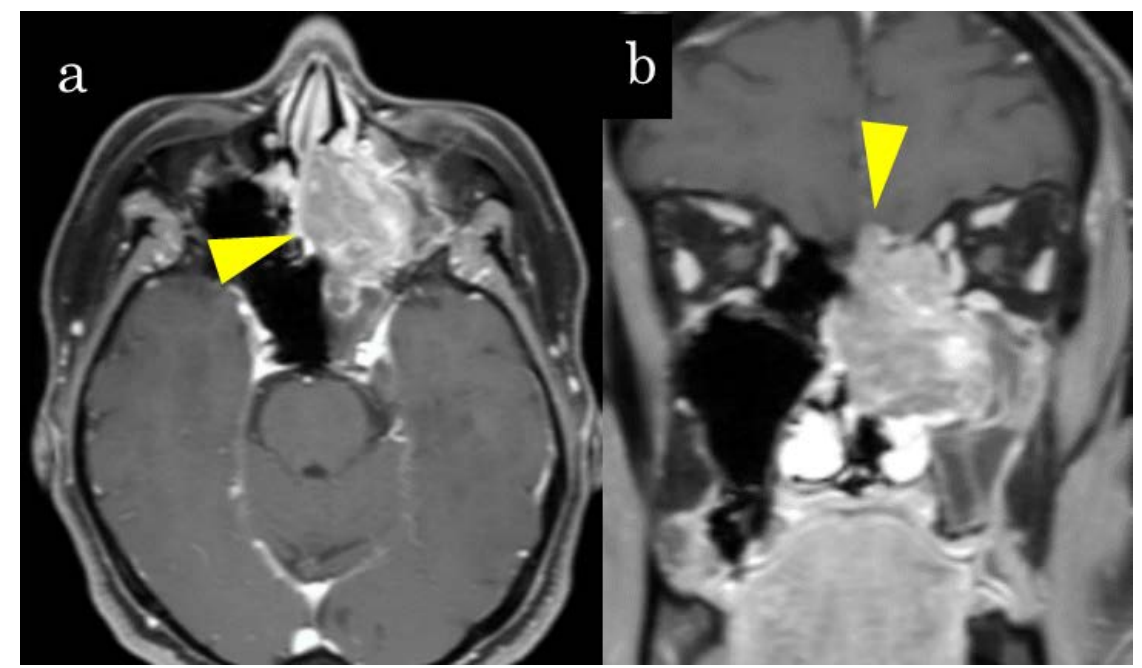

図8 症例 $39 \mathrm{MRI}$ 像。造影 $\mathrm{T} 1$ 強調画像で，等信号で造影効果のある腫瘍を左篩骨洞から左上顎洞，左上鼻道，左中鼻道，左総 鼻道，左蝶形骨洞にわたり認め ( $\mathrm{a}$ 矢頭)，硬膜浸潤を疑う硬膜肥厚所見も認める ( $\mathrm{b}$ 矢頭)。左前頭蓋底には近接している が, 同部の浮腫, 浸潤所見は認めない。 $\mathrm{a}:$ 水平断像。 $\mathrm{b}$ ：冠状断像。

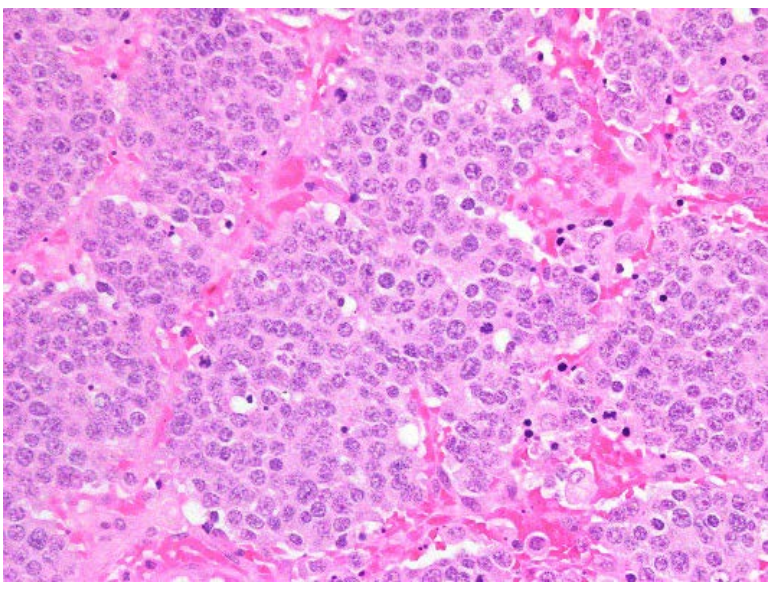

図9 症例 3 の病理組織像。円形細胞腫瘍で, 細胞質にそし く濃染する円形腫大核を有する腫瘍細胞が充実性に増 生している。

隔，総鼻道，下鼻道の粘膜で構成する右拡大有茎鼻腔粘 膜弁でさらに被覆した。採取する筋膜はある程度の大き さを確保でき，採取創部が外見上目立たない大腿筋膜を 選択した。

術後2週間経過時点で術後化学放射線療法を施行した。 化学療法はシスプラチン $\left(80 \mathrm{mg} / \mathrm{m}^{2}\right.$ : day 1) を 3 コース, 3 週間毎に施行した。放射線治療はIMRTで $66 \mathrm{~Gy} / 33$ 回 とした。右視神経への線量は $50.5 \mathrm{~Gy}$, 左視神経への線量 は66.6 Gyであった。左視神経は術前の病変が近接して いたため，耐用線量を越えて照射した。治療後，MRIで 腫瘍残存を認めなかった（図 10-a, b)。しかし，治療終 了後3カ月でのMRIで硬膜播種を認めた（図10-c）。二ボ ルマブを導入したが奏功せず, 初回治療終了から 10 月月
（診断から 13 カ月）で死亡した。

症例 $4: 52$ 歳 女性

主訴：左顔面痛

現病歴：当科受診 4 力月前より左顔面痛を自覚し, 近 医耳鼻咽喉科診療所で副鼻腔炎の診断で治療を受けた が症状が改善せず，左鼻副鼻腔腫瘍疑いで当科へ紹介さ れた。

PET-CT所見：左篩骨洞から総鼻道, 左上顎骨, 左㚘頁 骨にわたり集積を認め，左眼窩内への伸展も認めた。左 頸部リンパ節への集積を認めた（図 11）。

病理組織学的所見：円形細胞腫瘍で, 類円形核を有す る細胞が大小の胞巣を形成して増生していた。HE所見 および免疫染色所見（表1）から鼻副鼻腔未分化癌と診 断された。

診断：左篩骨洞未分化癌。cT4aN2bM0, Stage IVA 治療：根治目的で化学放射線療法を施行した。化学療 法はFP療法を3コース，4週間毎に施行した。放射線治 療はIMRTで70 Gy/35回とした。右視神経への線量は $71.1 \mathrm{~Gy}$, 左視神経への線量は50.0 Gyであった。右視神経 は病変近接のため, 耐用線量を超えた治療選択とした。 治療後PET-CTで原発巣, リンパ節転移の消失を認めた (図 12-a, b)。しかし，同PET-CTで多発肺転移，肝転移 を認め（図12-c, d)，ニボルマブ導入するも奏効せず, 初回治療終了から 7 力（診断から 12 力）で死亡した。

当科で経験した 4 症例の一覧を表に示す（表 2$) 。$ 


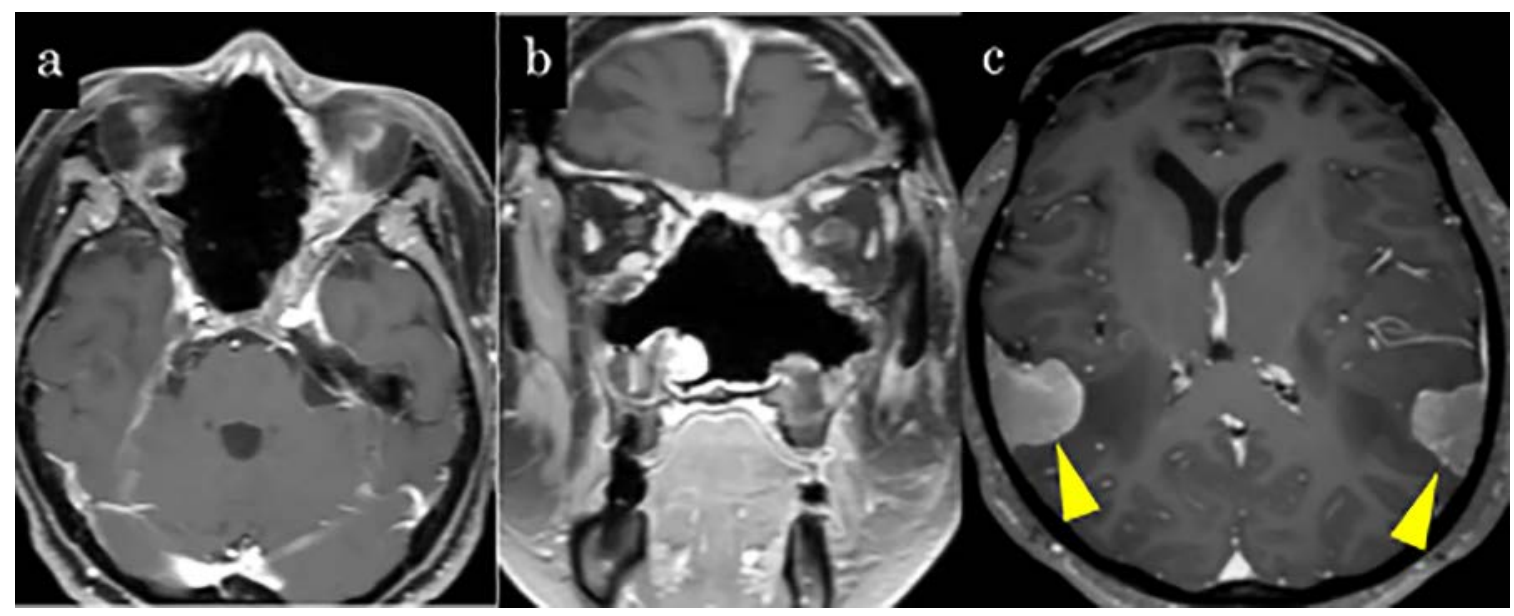

図 10 症例 3 の治療後 6 力月経過時のMRI像。造影 $\mathrm{T} 1$ 強調画像で原発巣の消失を認める。 $\mathrm{a}:$ 水平断像。 $\mathrm{b}:$ 冠状断像。 $\mathrm{c}:$ 造影 $\mathrm{T} 1$ 強調画像で硬膜播種像を認める (矢頭)。

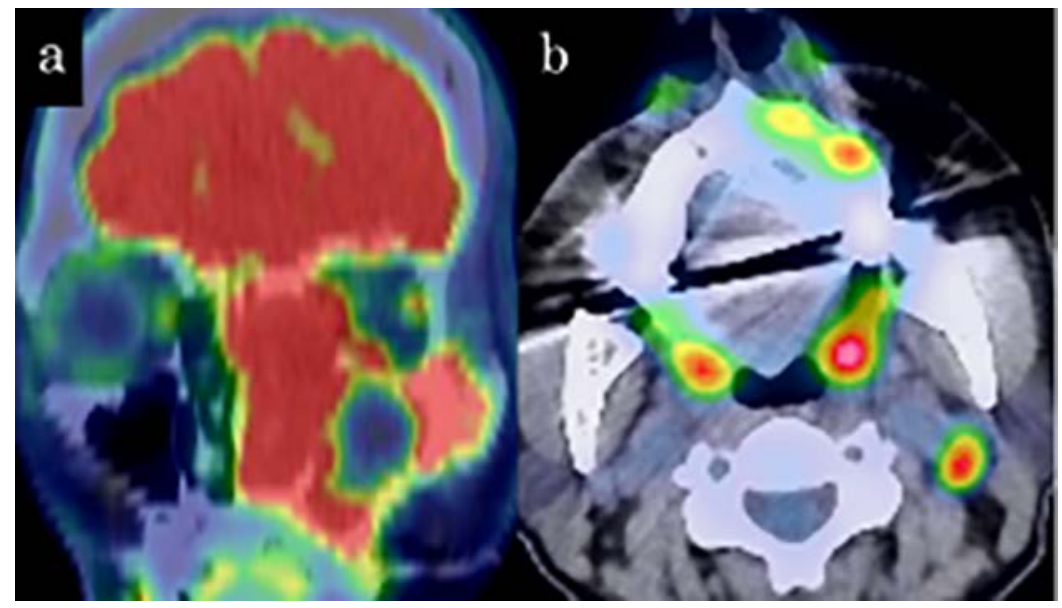

図11 症例 4のPET-CT像。a : 冠状断像。左篩骨洞から左眼窩内，左上顎骨，左煩骨にかけての集積を認める。 b: 水平断像。左 頸部リンパ節への集積を認める。

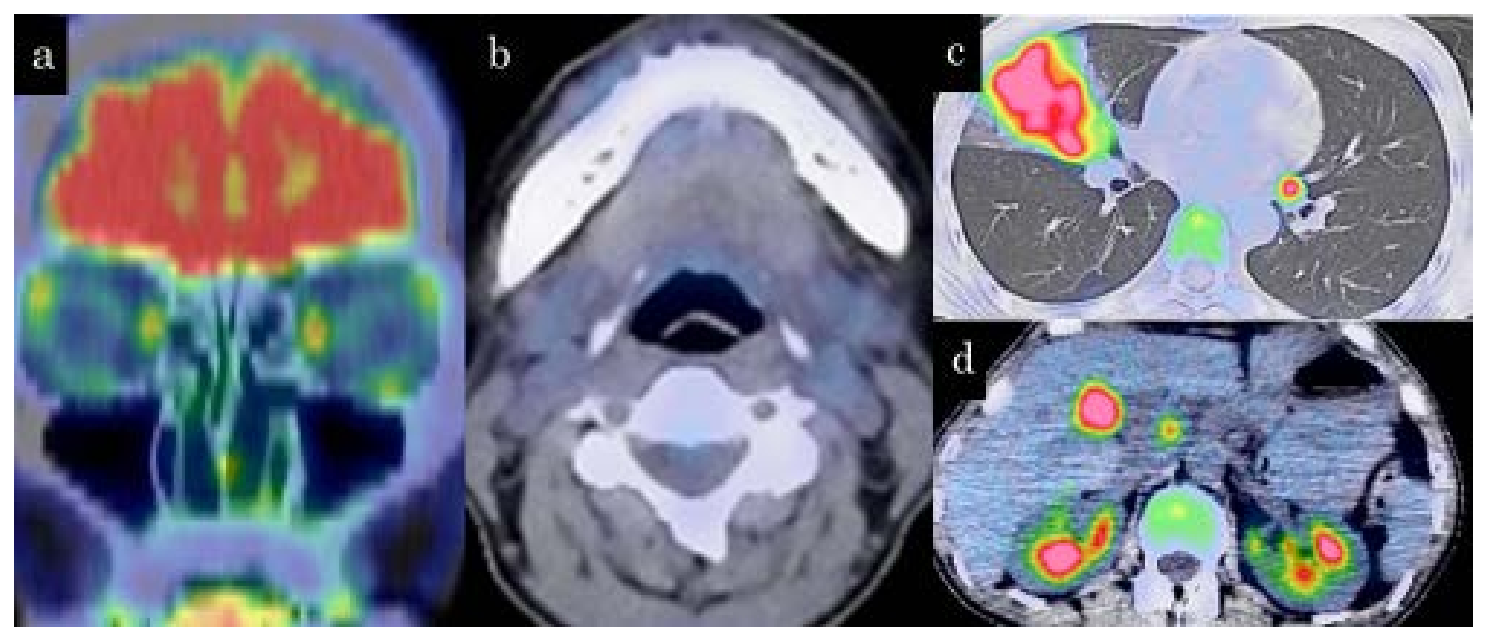

図 12 症例 4 治療後PET-CT像。原発巣，頸部リンパ節転移の消失を認める。 $\mathrm{a}$ : 冠状断像。 $\mathrm{b}:$ 水平断像。 $\mathrm{c}$ :胸部水平断像。胸 部多発肺転移像を認める。 $\mathrm{d}$ : 腹部水平断像。腹部肝転移像を認める。 
表2 自験例一覧

\begin{tabular}{clllllll}
\hline 症例 & 原発巣 & TNM & 手術 & 化学放射線療法 & \multicolumn{1}{c}{ 放射線 } & 化学療法 & 予後 \\
\hline 1 & 蝶形骨洞 & - & なし & 根治目的 & $36 \mathrm{~Gy} / 12$ 回+10 Gy/1回 & $\mathrm{FP}$ & 無病生存 \\
2 & 鼻腔 & T4aN0M0 & 施行 & 術後 & $60 \mathrm{~Gy} / 30$ 回 & $\mathrm{FP}$ & 無病生存 \\
3 & 穊骨洞 & T4aN0M0 & 施行 & 術後 & $66 \mathrm{~Gy} / 33$ 回 & $\mathrm{CDDP}$ 単独 & 原病死 \\
4 & 篩骨洞 & T4aN2bM0 & なし & 根治目的 & $70 \mathrm{~Gy} / 35$ 回 & $\mathrm{FP}$ & 原病死 \\
\hline
\end{tabular}

\section{考察}

鼻副鼻腔未分化癌についての単施設からの報告では, 5 年生存率 $20 \sim 74 \%{ }^{4 \sim 11)}$ と幅があり，1報告中の症例数は 1〜21症例と多くはなく，まさに希少がんであることを 示している。病理学的には分化傾向を特定できない癌腫 と定義され，いわゆる腫瘍性の小円形細胞腫瘍を組織内 に認める。鼻副鼻腔未分化癌は何らかの分化傾向を示す あらゆる癌腫を否定する必要があり，鑑別すべき癌腫は 多岐にわたる。さらに癌腫以外の悪性腫瘍との鑑別も必 要となる場合がある。したがってHE染色だけでの確定診 断はきわめて困難である。腫瘍が円形細胞を呈した場合, 代表的鑑別疾患には類基底細胞扁平上皮癌, 小細胞癌, 大細胞神経内分泌癌を含む神経内分泌腫瘍, SMARCB1deficient carcinoma，NUT carcinomaなどの癌腫，悪性 リンパ腫や嗅神経芽細胞腫，Ewing肉腫を含む未分化円 形細胞肉腫の一群が挙げられる。未分化円形細胞肉腫の 診断には融合遺伝子等の詳細な検討が必要で, 世界でも 限られた施設でしか診断できない。今回提示した 4 症例 はいずれもサイトケラチンが一定程度染色されており癌 腫と判断している，HE染色における核所見やロゼット 形成や器官様パターンを欠いた組織構築と免疫染色所見 を総合的に鑑みて神経内分泌腫瘍を除外している。さら に症例 4 のみサイトケラチン $5 / 6$ が部分的に陽性である が，p40，p63はいずれも院性であり，扁平上皮分化を欠 いていると判断した。以上からいずれの症例も鼻副鼻腔 未分化癌と診断している。症例 1 ではINI1 除性であるが, SMARCB1-deficient carcinomaで多いとされるbasaloid featuresやplasmacytoid/rhabdoid featuresを欠いてい ることからSMARCB1-deficient carcinomaを否定してい る。SMARCB1-deficient carcinomaは比較的新しい疾患 概念であり，形態的に典型ではないINI1 陰性症例の取り 扱いは定まっていない。FISHによるSMARCB1 欠失の 確認は必ずしも必要とされていないが, 疾患概念の確立 とともに症例 1 はSMARCB1-deficient carcinomaに分類 される可能性はある。

鼻副鼻腔未分化癌は希少がんであるため, 標準治療法が
まだ確立されていないが，これまでの報告に共通して手 術, 化学療法, 放射線治療を複合して行うことが重要と されている。そして，これら3つのモダリティを使用し た群ではそれ以外の群と比較して有意に 5 年生存率が長 かったことも報告されている ${ }^{12)}$ 。ただし，手術不能例や 化学放射線療法に耐えられる全身状態でない症例も含ま れるため，3つのモダリティを使用できる例で成績が良 いのは当然かもしれないが，実際に3つのモダリティを 使用できずに2つのモダリティだけでの治療を施行した 例では局所制御不良の因子であったという報告がある ${ }^{4)}$ これらを参考に，当施設では手術可能症例にはまず手術 での根治切除を目指し, 根治切除ができてもその病理学 的悪性度を考慮して術後化学放射線療法を併用してい る。その結果, 現時点で 4 例中 2 例と半分の症例が無病 生存中という結果である。悪性度の高い疾患なので, 可 能であれば多くのモダリティで集学的に治療を施行する のは理にかなっていると考えられる。

手術単独療法は化学療法, 放射線治療と比較して, 単 独のモダリティでの治療としては最も生存率が高いと報 告されており ${ }^{10)}$, 手術例の方が保存的療法例よりも局所 制御率が高かったとする報告がある ${ }^{4)}$ 。しかし，眼窩尖 端部，脳実質，側頭下窩，海綿静脈洞への浸潤例は手術 不能であり，これらの症例では1つのモダリティが久け てしまうため，局所制御不良となる ${ }^{4)}$ 。なお，前述の報 告 ${ }^{4)}$ では, 切除可能かどうか疑問視される症例には導入 化学療法を施行し, ダウンステージングしてから手術・ 術後放射線治療を施行することで3つのモダリティを使 用した治療としている。しかし手術不能例として初回治 療から根治的化学放射線療法になる症例との明確な線引 きがなく，これらを抽出して比較検討もなされていない ため, 導入化学療法に手術と術後放射線治療を加えた治 療と根治的化学放射線療法の効果の差は不明である。今 回の当施設の検討例は手術と術後化学放射線療法を施行 した例と化学放射線療法のみ施行した例が 2 例ずつで, それぞれにおいて 1 例治癒と 1 例死亡という結果に分か れた。またダウンステージングしてから手術・術後放射 線治療を施行した例はなかったので，これについての検 
討にはさらに症例を蓄積した上での再検討を要すると考 える。

化学療法の標準化されたレジメンは現時点では確立さ れてないが, シスプラチンやカルボプラチンにエトポシ ドやフルオロウラシルを追加するレジメンやシクロホス ファミド+ドキソルビシン +ビンクリスチンを用いたレ ジメンが多くみられる。ただし，これらのレジメンによ る治療効果の差を検討した報告はない。当施設の化学療 法は過去の報告で最も多いプラチナベースのレジメンと している。症例 3 は当診療科における最初の未分化癌手 術例であったが, 手術が病理学的に根治切除であったこ とと, 複数抗癌薬使用で生じうる有害事象により治療完 遂の可能性が低下することを懸念して, 抗癌薬をシスプ ラチン単独使用とした。

放射線治療については, IMRTで 60 Gy以上の線量を 照射することにより通常照射と比較して予後を改善する と報告されており ${ }^{12)}$ ，これを参考に当施設でも放射線治 療をIMRTで最低量 60 Gy照射としている。また, IMRT の副作用については，2次元照射・3次元原体照射を比較 した検討においてIMRT群の方が視機能障害が有意に少 なく, 2 次元照射・ 3 次元原体照射群でみられた失明の有 害事象はIMRT群では皆無であったと報告されており ${ }^{4)}$, 鼻副鼻腔未分化癌に対してIMRTは適していると考えら れる。当施設では病側の視神経への線量については手術 と術後放射線治療を併用した症例では手術後の所見や再 発リスクに応じて, 耐用線量を越えた線量投与を許容す るか決定しており, 手術なし（化学放射線療法）で視神 経に近接している症例では原則として病側（片側のみ） の視神経については耐用線量を越えた線量投与を許容し ている。近年, 鼻副鼻腔癌において粒子線治療が光子線 治療 $(X$ 線治療やガンマ線治療) より良い治療結果であっ

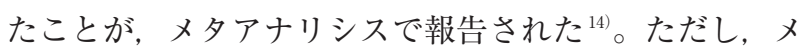
タアナリシスの中で対象となった報告のほとんどが後 ろ向きの観察研究であり, 組織型も多様であったことか ら，臨床試験において検討することが必要である。粒子 線治療はブラッグピークを有することから正常組織の線 量低減や線量集中性の点で優れており, 今後は粒子線治 療を含めた集学的治療が期待される。

なお，手術不能例に対しては根治的な化学放射線療法 を施行している。治療法のモダリティが2つに減るが, 症例 1 においてはこの治療方法で治癒状態となった。本 症例を治療した時期にはまだ当施設にIMRT設備がな く, 腫瘍の進行が速く, 急な視機能障害も生じたことか ら, 脳神経外科と相談して 1 回線量を上げ, 広範囲定位 放射線治療を追加する方法を施行した。モダリティが少
ない例でも，中には症例 1 のように治癒する例があるこ とは, 病期が進行した例であってもまずは可能な限りモ ダリティを複合的に施行することの意義を示唆してい る。実際に今回報告した 4 症例はすべてStage IVAまた はIVBの進行期例で，遠隔転移を生じた 2 例も含めて全 例で局所制御は良好であり，そして 4 例中 2 例が無病生 存している。

一方，局所制御が良好でも遠隔転移を認めた例は予後 不良である。従来の殺細胞性の化学療法では遠隔転移を 制御できなかった。過去の報告でも鼻副鼻腔未分化癌に おいては局所再発, 遠隔転移例の救済が困難であったと されている ${ }^{4)}$ 。最近，これに対する新たな治療法として 生物学的製剂が注目されている。本邦でも2017年3月か ら再発又は遠隔転移を有する頭頸部癌に対してニボルマ ブの医療保険適用が追加され，鼻副鼻腔未分化癌に対し ても使用が可能となっている。ただし，ニボルマブの有 用性を示したCheckMate141 試験の結果で有効性を示し たのはプラチナ抵抗性頭頸部扁平上皮癌のみであり ${ }^{15)}$, 鼻副鼻腔未分化癌に対するエビデンスを示した報告は今 のところない。実際，当科で遠隔転移例 2 例に「再発又 は遠隔転移を有する頭頸部癌」として使用したが奏効せ ず，遠隔転移が増大して死亡に至った。これについては 今後さらなる症例蓄積により有効性の有無を検討する必 要がある。今後の展望として, 鼻副鼻腔未分化癌の予後 因子は遠隔転移であり，これを制御できる治療法が確立 すれば本疾患の予後は格段に向上することが期待できる と考える。

\section{まとめ}

1）当施設で診療した鼻副鼻腔未分化癌4症例の臨床像を 報告した。

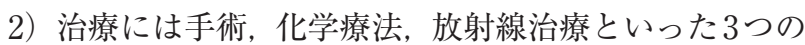
モダリティを併用することが良好な予後のために必 要である。

3）手術は手術可能症例であれば根治切除を目指し,放射 線は基本的にはIMRTで60 Gy以上の線量を照射し， 化学療法はプラチナベースのレジメンを用いること で局所制御は良好にコントロール可能と考えられる。

4）遠隔転移は予後不良因子であり，この制御が今後の予 後改善のための重要な課題である。

\section{参考文献}

1) Chambers KJ, Lehmann AE, Remenschneider A, et al: Incidence and survival patterns of sinonasal undifferentiated carcinoma in the United States. J 
Neurosurg B Skull Base 2015; 76: 94-100.

2) Neil B: Cancer of the nasal cavity survival and factors influencing prognosis. Arch Otolaryngol Head Neck Surg 2002; 128: 1079-1083.

3) Mohemmed NK, Neeraja K, Arjun P, et al: Treatment modalities in sinonasal undifferentiated carcinoma; An analysis from the national cancer database. Int Forum Allegy Rhinol 2017; 7: 205-209.

4) Mamgani AA, Rooij P, Mehilal R, et al: Combinedmodality treatment improved outcome in sinonasal undifferentiated carcinoma: Single-institutional experience of 21 patients and review of the literature. Eur Arch Otorhinolaryngol 2013; 270: 293-299.

5) Chen AM, Daly ME, El-Sayed I, et al: Patterns of failure after combined-modality approaches incorporating radiotherapy for sinonasal undifferentiated carcinoma of the head and neck. Int $\mathrm{J}$ Radiat Oncol Biol Phys 2008; 70: 338-343.

6) Musy PY, Reibel JF, Levine PA: Sinonasal undifferentiated carcinoma: The search for a better outcome. Laryngoscope 2002; 8: 1450-1455.

7) Lin EM, Sparano A, Spalding A, et al: Sinonasal undifferentiated carcinoma: A 13-year experience at a single institution. Skull Base 2010; 20: 61-67.

8) Rosenthal DI, Barker JL Jr, El-Nagger AK, et al: Sinonasal malignancies with neuroendocrine differentiation: Patterns of failure according to histologic phenotype. Cancer 2004; 101: 2567-2573.
9) Tanzler ED, Morris CG, Orlando CA, et al: Management of sinonasal undifferentiated carcinoma. Head Neck 2008; 5: 595-599.

10) Miyamoto RC, Gleich LL, Biddinger PW, et al: Esthesioneuroblastoma and sinonasal undifferentiated carcinoma: Impact of histological grading and clinical staging on survival and prognosis Laryngoscope 2000; 8: 1262-1265.

11) Rischin D, Porceddu S, Perters L, et al: Promising results with chemoradiation in patients with sinonasal undifferentiated carcinoma. Head Neck 2004; 5: 435-441.

12) Mauricio EG, Devyani L, Michele $Y$, et al: Outcomes and patterns of failure for sinonasal undifferentiated carcinoma (SNUC): The Mayo Clinic Experience. Head Neck 2018; 39: 1819-1824.

13) Reiersen DA, Pahilan ME, Devaiah AK: Metaanalysis of treatment outcomes for sinonasal undifferentiated carcinoma. Otolaryngol Head Neck Surg 2012; 147: 7-14.

14) Patel SH, Wang WW, Mohammed K, et al: Charged particle therapy versus photon therapy for paranasal sinus and nasal cavity malignant disease: A systematic review and meta-analysis. Lancet Oncol 2014; 15: 1027-1038.

15) Robert LF, George B Jr, Jerome F, et al: Nivolumab for recurrent squamous-cell carcinoma of the head and neck. N Engl J Med 2016; 375: 1856-1867. 